\title{
Kinetics of zinc transformation in calciorthids soils of western Rajasthan, India
}

\author{
Manoj Kumar Sharma, Bhim Singh* and C.K. Arya \\ College of Horticulture and Forestry, Jhalarapatan, Jhalawar -326 023 (Rajasthan), INDIA \\ *Corresponding author. E-mail: bhimsingh1@gmail.com
}

Received: March 4, 2014; Revised received: March 22, 2014; Accepted: April 5, 2015

\begin{abstract}
The present study was under taken to investigate the kinetics of transformation process of applied and native $\mathrm{Zn}$ as influenced by soil moisture regime, available moisture and organic matter additions in Aridisols of western Rajasthan. The incubation experiment was conducted with exact amount of the soil samples (250 g), put in a number of small containers, made of corning glass. Three levels of moisture regimes i.e. field capacity $\left(\mathrm{W}_{0}\right)$, continuous submergence $\left(\mathrm{W}_{1}\right)$, alternate submergence and saturation $\left(\mathrm{W}_{2}\right)$ and two levels of organic matter as starch at 0 per cent $\left(\mathrm{M}_{1}\right)$ and 0.5 per cent $\left(\mathrm{M}_{2}\right)$ of the soil weight; and two levels of zinc i.e. native $(\mathrm{N})$ and applied $(A)(\mathrm{Zn} @ 5 \mathrm{mg}$ $\mathrm{kg}^{-1}$ soil as $\mathrm{ZnSO}_{4} .7 \mathrm{H}_{2} \mathrm{O}$ ). The soils then incubated for 30,60 and 90 days. Destructive sampling was done after each incubation period, and then different fractions of $\mathrm{Zn}$ were sequentially extracted by different extracting solutions and determined with the help of atomic absorption spectrophotometer. Based on the results, it can be concluded that the transformation of $\mathrm{Zn}$ is largely controlled by organic matter, moisture regimes and $\mathrm{Zn}$ application due to considerable changes in the chemical and electrochemical properties of soil and thereby influence the transformation of zinc. Organic matter application significantly increased $\mathrm{Zn}$ fractions due to the retention of $\mathrm{Zn}$ on exchange complex owing to producing organic acid by decomposition of organic matter in soil. Further, the results showed that if such condition was maintained in the field, and it increased the availability of $\mathrm{Zn}$ for different crops in Aridisols.
\end{abstract}

Keywords: Amorphous sesquioxide bound, Aridisols, Calciorthids exchangeable, Crystalline sesquioxide bound Zn, Organic complexed

\section{INTRODUCTION}

Soils, the medium of plant growth is biologically vibrant and chemically active. Therefore, behavior of native or applied nutrients is continuously modulated by a number of biochemical processes (Reyhanitabar and Gilkes, 2010). The studies that determine how changes in properties bring micronutrients into available forms are of at most importance, especially to determine from which form they become available and what changes are necessary to cause redistribution. Plants take their nutrients mostly from soil. It is well known that the optimum plant growth and crop yield depends not only on the total amount of nutrients present in the soil at a particular time but also on their availability which in turn is controlled by physico-chemical properties like: soil texture, organic carbon and calcium carbonate, cation exchange capacity, $\mathrm{pH}$ and electrical conductivity of soil (Bell and Dell, 2008). Thus, not only are the form themselves important, but possibly to even greater significance are the potential changes among forms due to outside influences. Transformation of micronutrient includes (Viets, 1962) precipitation, fixation, or interlattice entrapment (occluded nutrients) by clay minerals, immobilization or conversion of nutrients into organic forms, sorbed on the soil exchange complex, and water soluble fraction.

The soil solution is the central focus of soil chemistry, since it is from this medium that plants absorb nutrients and it is the center of all chemical processes (Lindsay, 1979). Soil water is known to regulate the kinetics of precipitation and dissolution of micronutrients by controlling the chemical as well as microbiological redox potential (Ponnamperuma, 1972). Soil water content is most important, in that, under wet conditions, elements dissolve or move by diffusion. The element concentrations in soil solution are in constant flux, influenced by a host of factors including soil types, moisture regimes, $\mathrm{pH}$, temperature, oxidation/reduction status, organic matter, fertilizer additions and plant uptake (Ponnamperuma, 1972).

Aridisols are mineral soil occurring extensively in the western half of Rajasthan divided by Aravali axis (Joshi et al., 1983). The region (Agro-climatic zone) falls under zone IA of Arid western region includes the districts of Jodhpur and Barmer. Soil types in this zone are desert soils and sand dunes, aeolian soil, coarse sand texture and in some places calcareous. Major portion of Aridisols in Rajasthan is covered by the sub-order orthids, which have one or more pedogenic 
horizons, these horizons form the basis for defining the great group of this sub-order, camborthids, calciorthids, salorthids and paleorthids, which commonly occur in the state. There are sporadic reports of zinc deficiency in these soils (Joshi and Sharma, 1986). Therefore, present study has been under taken to investigate the kinetics of transformation process of applied and native $\mathrm{Zn}$ as influenced by soil moisture regime, available moisture and organic matter additions in Aridisols of western Rajasthan.

\section{MATERIALS AND METHODS}

Sampling site and climate: Aridisols are mineral soil occurring extensively in the western half of Rajasthan divided by Aravali axis. The region falls under zone IA -Arid western (where average rainfall between 200 to $370 \mathrm{~mm}$ ) of Agro-Climatic Zones includes the districts of Jodhpur and Barmer. Soil types in this zone are desert soils and sand dunes, aeolian soil, coarse sand texture and in some places calcareous. Major portion of Aridisols in Rajasthan is covered by the sub-order orthids, which have one or more pedogenic horizons, these horizons form the basis for defining the great group of this sub-order, camborthids, calciorthids, salorthids and paleorthids, which commonly occur in the state. The winter season rudiments from second half of October and continue up to February last. The period of summer season was long compared to winter, beginning from March to first half of July. Bulk soil sample $(25-30 \mathrm{~kg})$ from surface layer $(0-15 \mathrm{~cm})$ were collected from the farmer's field at nearby areas of Jodhpur district, representing major calciorthids great group soil of western Rajasthan and prepare composite sample for the study.

Determination of physico-chemical characteristics of the soil: Soil sample was air dried in shadow, gently crushed with a wooden pastle and passed through 2 $\mathrm{mm}$ sieve. Processed soil sample used for detail laboratory analysis. The $\mathrm{pH}$ and Electrical Conductivity of soil was determined in 1:2 soil water suspension (Richards, 1954), mechanical composition by Hydrometer method (Bouyoucos, 1951), organic carbon by rapid titration method (Walkley, 1947), calcium carbonate by titration method (Piper, 1950) and cation exchange capacity by centrifuge method (Richards, 1954).

Incubation study: The incubation experiment was conducted in Department of Agricultural Chemistry and Soil Science laboratory, Rajasthan College of Agriculture, Udaipur, which is located at latitude of $24.3^{\circ} \mathrm{N}$ and longitude of $73.4^{0} \mathrm{E}$ and at an altitude of 583 meters above mean sea level. Exact amount of the soil samples (250 g) were put in a number of small containers, made of corning glass. Three levels of moisture regimes i.e. field capacity $\left(\mathrm{W}_{0}\right)$, continuous submergence $\left(\mathrm{W}_{1}\right)$, alternate submergence and saturation $\left(\mathrm{W}_{2}\right)$ and two levels of organic matter as starch at 0 percent $\left(\mathrm{M}_{1}\right)$ and 0.5 percent $\left(\mathrm{M}_{2}\right)$ of the soil weight; and two levels of zinc i.e. native (N) and applied (A) ( $\mathrm{Zn} @ 5 \mathrm{mg} \mathrm{kg}^{-1}$ soil as $\mathrm{ZnSO}_{4} .7 \mathrm{H}_{2} \mathrm{O}$ ). Starch (A.R. Grade), instead of any conventional manure, was used to avoid any complication that might arise due to the release of mineral elements from the decomposition of such organic matter. The experiment was laid dawn in completely randomized design (CRD) with factorial concept. The treatment combinations were 12 in number $\left(\mathrm{W} 0 \mathrm{M} 1 \mathrm{~N}, \mathrm{~W}_{0} \mathrm{M}_{1} \mathrm{~A}\right.$, $\mathrm{W}_{1} \mathrm{M}_{1} \mathrm{~N}, \mathrm{~W}_{1} \mathrm{M}_{1} \mathrm{~A}, \mathrm{~W}_{2} \mathrm{M}_{1} \mathrm{~N}, \mathrm{~W}_{2} \mathrm{M}_{1} \mathrm{~A}, \mathrm{~W}_{0} \mathrm{M}_{2} \mathrm{~N}, \mathrm{~W}_{0} \mathrm{M}_{2} \mathrm{~A}$, $\mathrm{W}_{1} \mathrm{M}_{2} \mathrm{~N}, \mathrm{~W}_{1} \mathrm{M}_{2} \mathrm{~A}, \mathrm{~W}_{2} \mathrm{M}_{2} \mathrm{~N}, \mathrm{~W}_{2} \mathrm{M}_{2} \mathrm{~A}$ ) with three replications of each. The soils then incubated for 30, 60 and 90 days in ambient summer season. In the ambient summer temperature, the incubation experiment was started from the March 5 to June 5, in the laboratory. The ambient temperature during this period ranged from 29.3 to $41.2^{\circ} \mathrm{C}$ (maximum) and 9.9 to $26.2^{\circ} \mathrm{C}$ (minimum). Destructive sampling was done after each incubation period, and then different fractions of $\mathrm{Zn}$ were sequentially extracted by different extracting solution as per details outlined in flow sheet of fig. 1 (Mandal and Mandal, 1986) and determined with the help of atomic absorption spectrophotometer (GBC AAS Modal No. 932).

Statistical analysis: The data on different fractions of zinc were statistically analyzed using analysis of variance techniques (Fisher, 1949). Test of significance (F-test) was used for estimation of the treatment differences (Cochran and Cox, 1959). Critical differences were calculated to assess the significance between different fractions of $\mathrm{Zn}$ wherever they were found significant. In all the statistical tests, a significance level of 0.05 was chosen.

\section{RESULTS AND DISCUSSION}

The physico-chemical analysis of experimental soil revealed that it had sand $67.10 \%$, silt $18.60 \%$, clay $14.30 \%$, textural class sandy loam, $\mathrm{pH}(1: 2.5) 8.11$, EC (1:2.5) $0.52 \mathrm{dSm}^{-1}$, organic carbon $0.294 \%, \mathrm{CaCO}_{3}$ $4.90 \%$, CEC $12.08 \mathrm{c} \mathrm{mol}(\mathrm{p}+) \mathrm{kg}^{-1}$, moisture at field capacity (At $1 / 3$ bar) $5.52 \%$ and WHC $23.64 \%$, available nitrogen $203.4 \mathrm{~kg} \mathrm{ha}^{-1}$, available phosphorus $7.81 \mathrm{~kg} \mathrm{ha}^{-1}$, available potassium $379.70 \mathrm{~kg} \mathrm{ha}^{-1}$. Initially among different fractions of $\mathrm{Zn}$ water soluble + exchangeable $\mathrm{Zn}$ was minimum 0.41 followed by Organic complexed 0.45 , Crystalline Sesquioxidebound 0.64 and amorphous Sesquioxide-bound 0.95 $\mathrm{mg} \mathrm{kg}^{-1}$ were recorded.

The kinetics of $\mathrm{Zn}$ transformation in calciorthids great group soil at periodic intervals revealed that the application of organic matter @ 0.5 percent significantly increased the Organic Complexed, AMOX and CRYOX fractions of Zn, whereas, WSEX$\mathrm{Zn}$ decreased at all the three stages of incubation (Table 1). Data further indicated that irrespective of the organic matter levels, significant reduction in WSEX, Organic complexed and CRYOX fractions of $\mathrm{Zn}$ were observed after 30 days of incubation. However, the AMOX-Zn increased up to 90 days at 
both the levels of organic matter (i.e., 1.02, 1.17 and $1.22 \mathrm{mg} \mathrm{kg}-1$ for $\mathrm{M} 1$; and $1.13,1.38$ and $1.44 \mathrm{mg} \mathrm{kg}-1$ for M2). The organic matter application caused considerable decrease in these three fractions may be due to the complexation of $\mathrm{Zn}$ by organic ligands (Sims and Patrick, 1978) and microbial immobilization of Zinc (De Remer and Smith, 1964). Among the different fractions, the AMOX-Zn showed maximum increment due to application of organic matter at 60 and 90 days of incubation (i.e., 15.2 and $15.3 \%$, respectively). The increase might be due to the fact that under the reduced condition in soils there is an increase in the formation of hydrated oxides of $\mathrm{Fe}$ and $\mathrm{Mn}$ which are the freshly formed compound possess larger surface area and hence have strong adsorption capacity (Kumar and Basavaraj, 2008).

The transformation of $\mathrm{Zn}$ during 90 days of incubation at various levels of moisture showed that the maximum content of $\mathrm{Zn}$ was recorded under alternate submergence and saturation (W2), having the values as $0.63,0.53$ and $0.45 \mathrm{mg} \mathrm{kg}-1$ for WSEX-Zn; 0.95, 0.86 and $0.75 \mathrm{mgkg}^{-1}$ for Organic Complexed-Zn; 1.13, 1.40 and $1.49 \mathrm{mg} \mathrm{kg}^{-1}$ for AMOX-Zn and 1.17, 1.07 and $0.98 \mathrm{mg} \mathrm{kg}^{-1}$ for CRYOX-Zn, at 30, 60 and 90 days of incubation, respectively. The minimum content of all these fractions of $\mathrm{Zn}$ were observed at field capacity (W0) moisture level, at all stages of incubation. Among the different moisture levels, W1 and W2 for WSEX and CRYOX fractions of $\mathrm{Zn}$ at 90 days were increased. On the other hand, irrespective of the moisture levels, the values of AMOX-Zn at 60 and 90 days of incubation were at par, whereas, other three fractions viz., WSEX, Organic complexed and CRYOX fractions of $\mathrm{Zn}$ decreased significantly after 30 days of incubation.

The fractions of $\mathrm{Zn}$ under study, i.e., WSEX, Organic Complexed, AMOX and CRYOX were increases with the application of zinc to incubated soil and the increased were to the tune of 13.1, 16.0 and 14.6 per cent for WSEX-Zn; 17.2, 22.1 and 17.4 per cent for Organic Complexed-Zn; 11.4, 10.3 and 10.8 per cent for AMOX-Zn and 12.1, 11.2 and 9.3 per cent for CRYOX-Zn at 30, 60 and 90 days of incubation, respectively. Among the different fractions, the CRYOX-Zn was maximum at 30 days, whereas, AMOX fraction of $\mathrm{Zn}$ was highest at 60 and 90 days of incubation, irrespective of the zinc levels.

Interactive effect of various treatments: The kinetics of $\mathrm{Zn}$ transformation was significantly affected by the interactive effects of organic matter, moisture and zinc application (Table 2, Fig. 2). The results showed that immediately after incubation, the extractable $\mathrm{Zn}$ content in WSEX, Organic complexed and CRYOX fractions recorded a marked decrease under 60 and 90 days of incubation; whereas, AMOX-Zn was increased significantly up to 90 days of incubation, without consideration of the various treatment combinations and temperature. The WSEX-Zn was maximum at alternate submergence and saturation, $0 \%$ organic matter, applied condition $\left(\mathrm{W}_{2} \mathrm{M}_{1} \mathrm{~A}\right)$ treatment and the decrease was more pronounced when the soils were treated with organic matter content. The minimum content was recorded at field capacity moisture level, $0.5 \%$ organic matter and native condition $\left(\mathrm{W}_{0} \mathrm{M}_{2} \mathrm{~N}\right)$ treatment, irrespective of the incubation period. Contrary to above findings, the organic complexed, AMOX and CRYOX fractions of $\mathrm{Zn}$ were increased with organic matter. treatment and zinc levels irrespective of the moisture levels and incubation periods. The maximum content of organic complexed, AMOX and CRYOX-Zn were observed at $\mathrm{W}_{2} \mathrm{M}_{2} \mathrm{~A}$ treatment (Alternate submergence and saturation, 0.5 $\%$ organic matter, Applied condition), whereas, minimum content of these fractions were recorded at treatment of field capacity moisture level combined with no organic matter application and native soil condition $\left(\mathrm{W}_{0} \mathrm{M}_{1} \mathrm{~N}\right)$, irrespective of the incubation periods. Application of organic matter caused a significant increase especially with alternate submergence and saturation, in the content of organic complexed, amorphous and crystalline sesquioxide bound fractions of $\mathrm{Zn}$. This may be attributed to the enhanced release of $\mathrm{Zn}$ present in mineral fractions as a result of action of decomposition products of added organic matter and enhanced microbial activity under these conditions (Dutta et al., 1989). The combined application of FYM along with $\mathrm{ZnSO} 4$ increased the content of Organic complexed-Zn which is possibly due to the release of $\mathrm{Zn}$ bound by crystalline sesquioxide on their reduction under submerged condition and its subsequent chelation by organic compound resulting from anaerobic decomposition of soil organic matter (Kumar and Basavaraj, 2008). Significant decrease in $\mathrm{Zn}$ fraction under field capacity was also reported by Phogat et al. (1994) and could be an account of weak stability of organically complexed $\mathrm{Zn}$ as suggested by Sims and Patrik (1978) and also to the subsequent transformations to amorphous sesquioxide form (Singh and Abrol, 1985; Mandal and Mandal, 1986). The data further showed that the WS+EX, Organic complexed and crystalline sesquioxide bound fractions of $\mathrm{Zn}$ decreased significantly after 30 days of incubation, irrespective of the various treatment combinations whereas, amorphous sesquioxide bound $\mathrm{Zn}$ increased significantly up to 90 days of incubation. Barring few treatment combinations the maximum content of $\mathrm{Zn}$ was observed in crystalline sesquioxide bound fraction at 30 days, while at 60 and 90 days amorphous sesquioxide bound $\mathrm{Zn}$ was maximum. These results are in conformity to earlier findings that the organic matter application caused considerable decrease in WS+EX-Zn fraction after 30 days of incubation and may be attributed to the complexation of $\mathrm{Zn}$ by organic ligands (Sims and Patrick, 1978). A number of investigators (Brar and Sekhan, 1976; Chatterjee et al., 1992) reported that the availablity of $\mathrm{Zn}$ in soil decreased with time may be due 
Table 1. Effect of organic matter, moisture and micronutrient levels on $\mathrm{Zn}$ fractions in Aridisols at different incubation periods.

\begin{tabular}{|c|c|c|c|c|c|c|c|c|c|c|c|c|}
\hline \multicolumn{13}{|c|}{ Zn Fractions $\left(\mathrm{mg} \mathrm{kg}^{-1}\right)$} \\
\hline \multirow[b]{2}{*}{$\begin{array}{l}\text { Treat- } \\
\text { ments }\end{array}$} & \multicolumn{3}{|c|}{ WSEX } & \multicolumn{3}{|c|}{ Organic complexed } & \multicolumn{3}{|c|}{$\overline{\text { AMOX }}$} & \multicolumn{3}{|c|}{ CRYOX } \\
\hline & $\begin{array}{c}30 \\
\text { days }\end{array}$ & $\begin{array}{c}60 \\
\text { days }\end{array}$ & $\begin{array}{c}90 \\
\text { days }\end{array}$ & $\begin{array}{c}30 \\
\text { days }\end{array}$ & $\begin{array}{c}60 \\
\text { days }\end{array}$ & $\begin{array}{c}90 \\
\text { days }\end{array}$ & $\begin{array}{c}30 \\
\text { days }\end{array}$ & $\begin{array}{c}60 \\
\text { days }\end{array}$ & $\begin{array}{c}90 \\
\text { days }\end{array}$ & $\begin{array}{c}30 \\
\text { days }\end{array}$ & $\begin{array}{c}60 \\
\text { days }\end{array}$ & $\begin{array}{c}90 \\
\text { days }\end{array}$ \\
\hline \multicolumn{13}{|c|}{ (A) Organic matter } \\
\hline M1 & 0.62 & 0.53 & 0.48 & 0.84 & 0.75 & 0.61 & 1.02 & 1.17 & 1.22 & 1.01 & 0.96 & 0.86 \\
\hline M2 & 0.53 & 0.50 & 0.42 & 0.87 & 0.77 & 0.66 & 1.13 & 1.38 & 1.44 & 1.17 & 1.06 & 0.98 \\
\hline SEm \pm & & 0.0056 & & & 0.0056 & & & 0.0049 & & & 0.0052 & \\
\hline $\mathrm{CD}$ at $5 \%$ & & 0.0157 & & & 0.0158 & & & 0.0138 & & & 0.0146 & \\
\hline \multicolumn{13}{|c|}{ (B) Moisture level } \\
\hline W0 & 0.50 & 0.48 & 0.43 & 0.78 & 0.69 & 0.55 & 1.02 & 1.21 & 1.22 & 0.99 & 0.93 & 0.82 \\
\hline W1 & 0.59 & 0.51 & 0.45 & 0.84 & 0.74 & 0.60 & 1.07 & 1.30 & 1.29 & 1.11 & 1.04 & 0.97 \\
\hline W2 & 0.63 & 0.53 & 0.45 & 0.95 & 0.86 & 0.75 & 1.13 & 1.40 & 1.49 & 1.17 & 1.07 & 0.98 \\
\hline SEm \pm & & 0.0068 & & & 0.0069 & & & 0.0060 & & & 0.0064 & \\
\hline $\mathrm{CD}$ at $5 \%$ & & 0.0193 & & & 0.0194 & & & 0.0170 & & & 0.0179 & \\
\hline \multicolumn{13}{|c|}{ (C) Zinc level } \\
\hline $\mathrm{N}$ & 0.53 & 0.47 & 0.41 & 0.77 & 0.67 & 0.57 & 1.01 & 1.22 & 1.24 & 1.02 & 0.95 & 0.88 \\
\hline A & 0.61 & 0.56 & 0.48 & 0.93 & 0.86 & 0.69 & 1.14 & 1.36 & 1.39 & 1.16 & 1.07 & 0.97 \\
\hline SEm \pm & & 0.0056 & & & 0.0056 & & & 0.0049 & & & 0.0052 & \\
\hline $\mathrm{CD}$ at $5 \%$ & & 0.0157 & & & 0.0158 & & & 0.0138 & & & 0.0146 & \\
\hline \multicolumn{13}{|c|}{ (D) Incubation periods } \\
\hline $\begin{array}{l}\text { Days } \\
\text { mean }\end{array}$ & 0.57 & 0.51 & 0.44 & 0.86 & 0.76 & 0.63 & 1.08 & 1.30 & 1.31 & 1.09 & 1.01 & 0.92 \\
\hline SEm \pm & & 0.0039 & & & 0.0040 & & & 0.0035 & & & 0.0037 & \\
\hline $\mathrm{CD}$ at $5 \%$ & & 0.0111 & & & 0.0112 & & & 0.0098 & & & 0.0103 & \\
\hline
\end{tabular}

Table 2. Dynamics of $\mathrm{Zn}$ fractions in Aridisols at various treatment combinations.

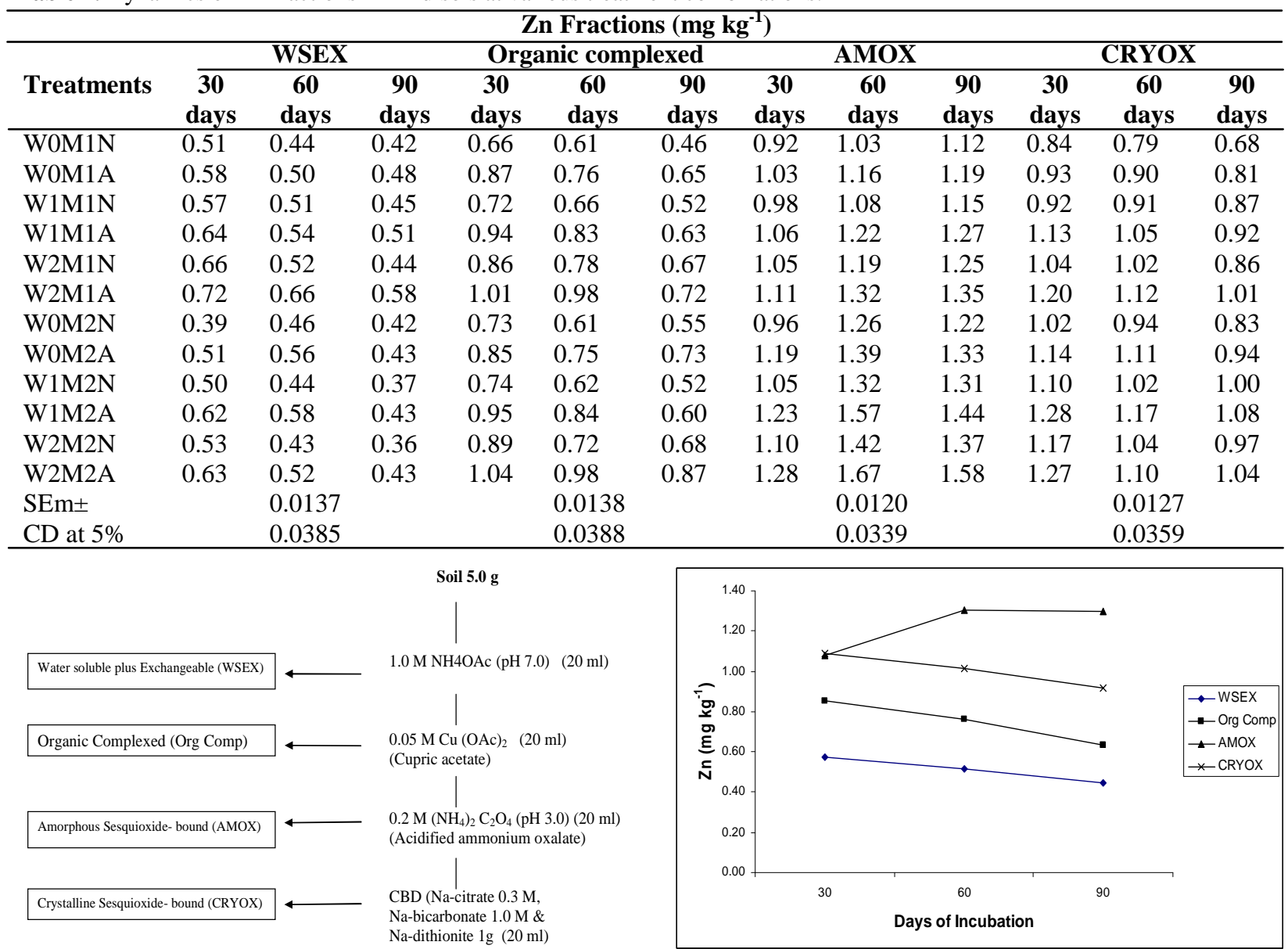

Fig. 1. Flow sheet for extraction of different fractions of zinc in soil.
Fig. 2. Kinetics of $\mathrm{Zn}$ transformation at different incubation periods. 
to sorption; whereas, Haldar and Mandal (1979) attributed this to the inactivation of soil $\mathrm{Zn}$ by the decomposing organic matter. Takkar and Sindhu (1979) reported that $\mathrm{Zn}$ concentration in the soil solution was regulated by both $\mathrm{Zn}(\mathrm{OH})^{2}-\mathrm{Zn}^{2+}(\mathrm{aq})$ and $\mathrm{ZnCO}_{3}-\mathrm{Zn}^{2+}$ (aq) systems during the initial periods and thereafter by $\mathrm{ZnCO}_{3}-\mathrm{Zn}^{2+}$ (aq) system alone because of the buffering effect of the soil carbonate equilibria. Similar findings were also observed by Mandal et al. (1993) and concluded that precipitation of $\mathrm{Zn}$ as hydroxide, carbonate and sulphide and it's adsorption on the surface of hydrated oxides of iron were at least partly responsible for the decrease.

The significant decrease in the WS+EX-Zn, particularly at 30 to 60 days of incubation were observed under the field capacity moisture regime and application of organic matter, than that of continuous submergence and alternate submergence and saturation and no organic matter application, and the effect was less prominent at later stage i.e. at 90 days of incubation. The decrease may be an account of favourable situation for microbial immobilization and precipitation of zinc as $\mathrm{ZnCO}_{3}$ and $\mathrm{Zn}\left(\mathrm{CO}_{3}\right)_{2} \mathrm{OH}_{2}$ (Brar and Sekhon, 1976; Joshi and sharma, 1986) and its adsorption on the surface of organic complexes under low Eh values (Sims and Patrick, 1978). Whereas, there was increase in the WS+EX$\mathrm{Zn}$ with application of organic matter under similar condition of incubation, which may be attributed to the retention of zinc on exchange complex and it is in conformity to the earlier reports (Mandal et al., 1988; Kumar and Basavaraj, 2008).

On the other hand, amorphous sesquioxide fraction of $\mathrm{Zn}$ increased continuously up to 90 days and the increase might be due to the transformation of WS+EX and Organic complexed fractions of $\mathrm{Zn}$ to amorphous sesquioxide fraction (Hazra et al., 1994) and also the transformation of stable native forms of $\mathrm{Zn}$. This could be attributed to the fact that the redox potential of the soils decreased to values where Fe was reduced and consequently, more amorphous oxides formed and sorbed the $\mathrm{Zn}$ released from other fractions (Ghanem and Mikkelsen, 1987). The higher content of amorphous sesquioxide bound zinc than crystalline sesquioxide bound zinc could be attributed to greater ability of amorphous sesquioxide to adsorb zinc because of their high specific surface area (Wani et al., 2013).

\section{Conclusion}

Based on the results, it can be concluded that the kinetics of $\mathrm{Zn}$ is largely controlled by organic matter, moisture regimes and $\mathrm{Zn}$ application due to considerable changes in the chemical and electrochemical properties of soil and thereby influence the transformation of zinc. Organic matter application significantly increased $\mathrm{Zn}$ fractions due to the retention of $\mathrm{Zn}$ on exchange complex owing to producing organic acid by decomposition of organic matter in soil. Further, the results showed that if such conditions were maintained in field, there would be an increase in the availability of $\mathrm{Zn}$ for different crops in Aridisols.

\section{REFERENCES}

Bell, R.W. and Dell, B. (2008). Micronutrients for sustainable food, feed, fibre and bioenergy production. First edition, IFA, Paris, France (www.fertilizer.org).

Bouyoucos, C.H. (1951). A recalibration of the hydrometer method for making mechanical analysis of soils. Agronomy Journal, 43:434-438.

Brar, M.S. and Sekhon, G.S. (1976). Effect of Fe and Zn on the availability of micronutrients under flooded and unflooded condition. Journal of the Indian Society of Soil Science, 24:446-451.

Chatterjee, J., Mandal, B., Hazra, G.C. and Mandal, L.N. (1992). Transformation of native and applied zinc in laterite soils under submergence. Journal of the Indian Society of Soil Science, 40:66-70.

Cochran, W.G. and Cox, G.M. (1959). Experimental designs. John Wiley and Sons, New York.

De Remer, E.D. and Smith, R.L. (1964). A preliminary study on the nature of zinc deficiency in field beans as determined by radioactive zinc. Agronomy Journal, 56:67-70.

Dutta, D., Mandal, B. and Mandal, L.N. (1989). Decrease in availability of $\mathrm{Zn}$ and $\mathrm{Cu}$ in acidic to near neutral soils on submergence. Soil Science, 147:187-195.

Fisher, R.A. (1949). Statistical tables for biological, agricultural and medical research. Oliver and Boy'd Ltd., Edinburg.

Ghanem, S.A. and Mikkelsen, D.S. (1987). Effect of organic matter on changes in soil $\mathrm{Zn}$ fractions found in wetland soils. Communications in Soil Science and Plant Analysis, 18:1217-1234.

Haldar, M. and Mandal, L.N. (1979). Influence of soil moisture regimes and organic matter application on the extractable $\mathrm{Zn}$ and $\mathrm{Cu}$ content in rice soils. Plant and Soil, 53:203-213.

Hazra, G.C., Patnayak, P.D. and Mandal, B. (1994). Effect of submergence on the transformation of zinc fraction in Alfisols in relation to soil properties. Journal of the Indian Society of Soil Science, 42:31-36.

Joshi, D.C., Dhir, R.P. and Gupta, B.S. (1983). Influence of soil parameters on DTPA extractable micronutrients in arid soils. Plant and Soil, 72:31-38.

Joshi, D.C. and Sharma, B.K. (1986). Adsorption and desorption of $\mathrm{Zn}$ by some sandy soils of arid Rajasthan. Journal of the Indian Society of Soil Science, 34:252263.

Kumar, K.H. and Basavaraj, B. (2008). Zinc transformation in calcareous Vertisol of Tungabhadra command. Karnataka Journal of Agricultural Sciences, 21(2):227-230.

Lindsay, W.L. (1979). Chemical equilibria in soils. John Wiley and Sons, Inc. New York

Mandal, B., Hazra, G.C. and Pal, A.K. (1988). Transformation of $\mathrm{Zn}$ in soils under submerged conditions and its relation with zinc nutrition of rice. Plant and Soil, 106:121-126.

Mandal, B., Mandal, L.N. and Ali, M.H. (1993). Chemistry of zinc availability in submerged soils in relation to zinc nutrition of rice crop. Proceedings of the Workshop on Micronutrients, 22-23 January, 1992, Bhubaneshwar, 
pp. 240-253.

Mandal, L.N. and Mandal, B. (1986). Zinc fractions in soils in relation to zinc nutrition of lowland rice. Soil Science, 142:141-148.

Phogat, V., Dahiya, D.J. and Singh, J.P. (1994). Effect of organic matter and soil water content on the transformation of native soil zinc. Journal of the Indian Society of Soil Science, 42:239-243.

Piper, C.S. (1950). Soil and plant analysis. Inter Science Publishers, Inc. New York.

Ponnamperuma, F.N. (1972). The chemistry of submerged soils. Advances in Agronomy, 24:29-96.

Reyhanitabar, A. and Gilkes, R.J. (2010). Kinetics of DTPA extraction of zinc from calcareous soils from Iran. 19th World Congress of Soil Science, Soil Solutions for a Changing World, 1 - 6 August 2010, Brisbane, Australia, pp. 19-22.

Richards, L. A. (1954). Diagnosis and improvement of saline and alkali soils. USDA Hand Book, No. 60, U.S. Department of Agriculture, Washington DC.

Sims, J.L. and Patrick, W.H. (1978). The distribution of micronutrient cations in soil under conditions of varying redox potential and $\mathrm{pH}$. Soil Science Society of America Journal, 42:258-262.

Singh, M.V. and Abrol, I.P. (1985). Transformation and availability of zinc in alkali soils. Fertilizer News, 31 (7):17-27.

Takkar, P.N. and Sindhu, B.S. (1979). Kinetics of zinc transformation in submerged alkaline soils in the rice growing tracts of Punjab. J. Agric. Sci., 93:441447.

Viets, F.G.Jr. (1962). Chemistry and availability of micronutrients in soils. Journal of Agricultural and Food Chemistry, 10:174-178.

Walkley, A. (1947). A critical examination of a rapid method for determining organic carbon in soils-Effect of variations in digestion conditions and of inorganic soil constituents. Soil Science, 63:251-264.

Wani, M.A., Bhat, M.A., Kirmani, N.A. and Nazir, S. (2013). Transformation of zinc and iron in submerged rice soils of Kashmir. Indian Journal of Agricultural Sciences, 83(11):1209-1216. 